\title{
STRATEGI PENGEMBANGAN MASYARAKAT DI ERA NEW NORMAL MELALUI PROGRAM CSR PT PETROKIMIA GRESIK
}

\author{
Aprilina Kurniawati \\ niaprilina@gmail.com \\ Ria Hermila \\ ria.hermila@petrokimia-gresik.com
}

PT PETROKIMIA GRESIK

\begin{abstract}
ABSTRAK
Program CSR Kampung Pisang Trepan merupakan pengembangan masyarakat yang melibatkan para pelaku UMKM. Mereka kesulitan mengelola keuangan, sumber daya manusia, dan pemasaran karena berbagai keterbatasan. Hal ini diperparah dengan kondisi pandemi Covid-19. Community Involvement and Development (CID) ISO 26000 dalam pelaksanaan program CSR di era new normal menjadi strategi yang paling tepat diterapkan untuk mencapai tujuan program yaitu menciptakan circular economy dengan memperhatikan dampak lingkungan. Pelaksanaan CID Program Kampung Pisang Trepan juga diselaraskan dengan Sustainable Development Goals (SDGs). Aktivitas masyarakat dalam Program Kampung Pisang Trepan berkontribusi meningkatkan kompetensi tambahan anggota kelompok sejumlah 72\%. Menurunkan pengangguran terbuka sebesar $0.0006 \%$ dari jumlah pengangguran terbuka di Kabupaten Lamongan. Serta mengurangi limbah melalui pemanfaatan limbah pelepah pisang menjadi kerajinan sebesar $500 \mathrm{~kg} / \mathrm{bulan}$.
\end{abstract}

Kata kunci: Community Involvement and Development, Corporate Social Responsibility Covid-19, New Normal, Sustainable Development Goals.

\section{PENDAHULUAN}

Program Kampung Pisang Trepan merupakan pengembangan masyarakat di Desa Trepan, Kecamatan Babat, Kabupaten Lamongan yang berfokus pada integrasi pengelolaan tanaman pisang. Program ini melibatkan Gabungan Kelompok Tani (Gapoktan) dalam kegiatan budidaya pisang. Sementara itu, pemanfaatan hasil panen dan limbah tanaman pisang dikelola oleh Kelompok Usaha Bersama (KUB) Pemuda Kreatif Trepan. KUB Pemuda Kreatif Trepan terdiri dari 4 UMKM yaitu (1)kerajinan pelepah pisang "Ibana Craft", (2)sambal pisang "Manoora", (3)semprong pisang "Sahitya" dan (4) brownies cips "Kennes Cake".

Implementasi program CSR di masa pandemi Covid-19 mengalami banyak penyesuaian. Hal ini merespon kondisi ekonomi masyarakat yang menurun akibat pandemi. Penelitian Soetjipto (2020) menyebutkan, selain sektor makanan dan minuman, sektor UMKM yang paling terdampak pandemi Covid-19 adalah industri kreatif dan pertanian. Aktivitas UMKM di Desa Trepan termasuk dalam sektor-sektor tersebut. 
Soetjipto (2020) menjelaskan lebih lanjut dalam penelitiannya bahwa $63 \%$ pelaku usaha di Jawa Timur mengalami penurunan pendapatan disebabkan menurunnya daya beli konsumen, $46 \%$ pelaku usaha menyatakan karena konsumen takut membeli, $46 \%$ pelaku usaha menyatakan karena adanya faktor pembatasan sosial berskala besar (PSBB) disertai sanksi, dan $42 \%$ lainnya menyatakan karena adanya aturan jam operasional buka toko. Kondisi tersebut mempengaruhi keputusan para pelaku usaha dalam menentukan strategi untuk bertahan. Dikutip dari data penelitian Soetjipto (2020), bahwa 38\% pelaku usaha memasarkan dagangannya melalui media online. Sementara itu $13 \%$ menitipkan dagangan ke toko yang masih buka, $8 \%$ pelaku usaha menyesuaikan jumlah produksi, dan $6 \%$ lainnya tetap buka stand.

Kondisi tersebut juga dirasakan oleh KUB Pemuda Kreatif Trepan yang mengalami penurunan pendapatan hingga 70\% di masa pandemi Covid-19. Dari hasil riset aksi partisipatoris, sebelum pandemi Covid-19, KUB Pemuda Kreatif Trepan Sahitya dan Kennes Cake sudah mengalami masalah dalam pemasaran dan tidak ada catatan keuangan. Sebagian besar pendapatan mereka berasal dari sistem penjualan online melalui whats app dan $e$ commers. Sedangkan masalah Ibana Craft terletak pada belum adanya branding produk, belum ada catatan keuangan, belum bisa mengoperasikan mesin produksi bahan baku, dan belum ada scale up usaha. Permasalahan tersebut disebabkan kurang optimalnya manajemen usaha.

Oleh karena itu, masa pandemi Covid19 ini dimanfaatkan oleh KUB Pemuda Kreatif Trepan untuk mengambil nafas sejenak dan meningkatkan kapasitas mereka dalam pengelolaan usaha. Pengembangan masyarakat merupakan bagian dari pembangunan berkelanjutan yang menekankan pada perbaikan kualitas hidup masyarakat dengan mengoptimalkan sumber daya. Pelaksanaannya bersifat partisipatoris. Tulisan ini menjelaskan aksi pengembangan kapasitas masyarakat dalam program CSR agar tetap bisa survive di era new normal. UMKM yang berkembang dapat mewujudkan desa wisata pisang dan menciptakan circular economy di Desa Trepan.

\section{METODOLOGI PELAKSANAAN}

Program pengembangan masyarakat "Kampung Pisang Trepan" dilaksanakan sejak Oktober 2018 dengan menerapkan prinsip community involvement and development (CID) ISO 26000. Pada era new normal dilakukan penyesuaian rencana kerja tahunan berdasarkan hasil riset aksi partisipatoris. Riset aksi partisipatoris melibatkan pihak-pihak rentan untuk mengidentifikasi masalah, mengumpulkan, menganalisis informasi, untuk menciptakan solusi yang paling sesuai dengan kebutuhan transformasi perubahan sosial (Selener,1997). Penulis bertindak sebagai katalisator sekaligus pembelajar bersama masyarakat.

Program Kampung Pisang Trepan dilaksanakan berdasarkan rencana strategis (5 tahun) dan dirinci menjadi kegiatan dalam rencana kerja tahunan. Dimulai dengan pelatihan ibu-ibu PKK A terdiri dari 20 orang tergabung dalam kelompok Sahitya yang mengolah berbagai macam makanan dari tanaman pisang seperti kerupuk kulit pisang, nugget bonggol pisang, dan sambal pisang. Kelompok PKK B terdiri dari 15 orang tergabung dalam Kennes Cake yang mengolah kue dengan bahan baku pisang. Sementara itu, Karang Taruna terdiri dari 20 orang membuat kerajinan pelepah pisang dalam kelompok Ibana Craft.

Kelompok UMKM mengikuti berbagai pameran di lingkup Kabupaten Lamongan hingga nasional. Pada tahun 2019, Kelompok Sahitya mendapatkan juara 1 lomba inovasi UMKM Desa se-Kabupaten Lamongan yang diselenggarakan Dinas Perindustrian dan Perdagangan Kabupaten Lamongan. Di tahun yang sama, Ibana Craft juga mendapatkan juara 1 Lomba Social Enterpreneur, Festival Inovasi Pemuda 
Nahdatul Ulama Provinsi Jawa Timur. Prestasi tersebut tidak berbanding lurus dengan peningkatan omzet usaha. Hal ini karena belum terbentuk mental wirausaha yang kuat. Solusi atas permasalahan ini adalah perbaikan mindset dan terus meningkatkan kualitas produk yang diwujudkan dalam Sekolah Kewirausahaan dan PIRT produk makanan.

Kelompok Ibana Craft terus berinovasi menciptakan produk kerajinan pelepah pisang. Pada tahun 2020, dilakukan pengembangan program yang fokus pada pengolahan limbah pelepah pisang menjadi kerajinan. Produksi kerajinan pelepah pisang membutuhkan area yang memadahi. Oleh karena itu dibuatlah Trepan Creative Space sebagai workshop bagi Ibana Craft sekaligus wahana untuk forum monitoring/diskusi bagi kelompok dan stakeholder.

\section{Roadmap Program Kampung Pisang Trepan}

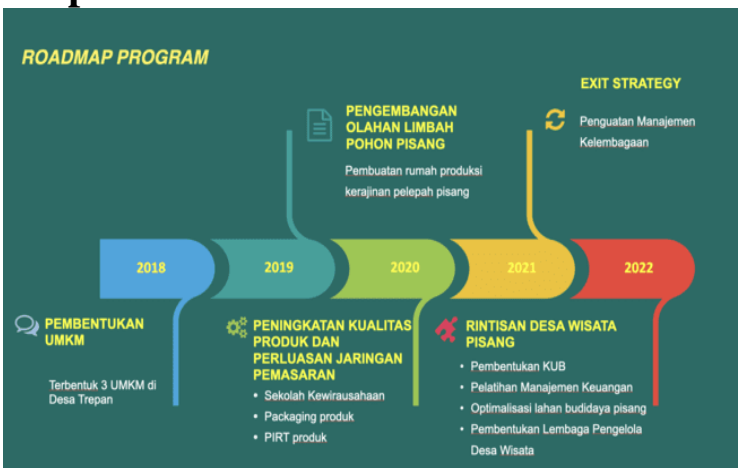

Gambar 1. Roadmap Program Kampung Pisang Trepan

Strategi pengembangan masyarakat pada tahun 2021 dipersiapkan untuk menghadapi era new normal, yang terbagi dalam beberapa tahapan:

a. Forum Monitoring Stakeholders.

Pelaksanaan program pengembangan masyarakat tidak terlepas dari peran serta para pemangku kepentingan. Forum monitoring ini menjadi salah satu kegiatan untuk diskusi dan mencari solusi dari berbagai dinamika dalam pelaksanaan program. Forum ini dilaksanakan secara berkala setiap 2 bulan sekali. Namun tidak menutup kemungkinan untuk dilaksanakan lebih intens.

b. Pembentukan Kelompok Usaha

Bersama.

Kelompok Usaha Bersama (KUB) lembaga berbadan hukum yang menaungi para pemuda dan pelaku usaha olahan pisang di Desa Trepan.

c. Pelatihan Manajemen Keuangan.

Peningkatan kapasitas dan kapabilitas anggota kelompok terus dilakukan, salah satunya dengan pelatihan manajemen keuangan. Kemampuan manajemen keuangan mendorong kedisiplinan kelompok dalam pengelolaan usaha.

d. Sertifikasi Halal Produk Olahan Makanan.

Perluasan jaringan pemasaran produk dapat dilakukan dengan produk yang memiliki sertifikasi halal. Sertifikasi halal diberikan untuk produk olahan makanan yaitu semprong pisang, brownies cips, dan sambal pisang.

e. Pembuatan Barcode Produk Olahan Makanan.

Pembuatan barcode produk merupakan salah satu upaya untuk menjangkau pasar retail nasional. Pembuatan barcode produk ini ditujukan untuk 3 jenis produk olahan makanan yaitu semprong pisang, brownies cips, dan sambal pisang.

f. Pembuatan Paket Oleh-Oleh.

Paket oleh-oleh menjadi salah satu hal yang khas dari desa wisata "Kampung Pisang Trepan". Paket oleh-oleh ini berisi produk kerajinan dan olahan makanan yang dapat digunakan sebagai souvenir bagi tamu yang berkunjung ke Desa Trepan. Paket oleh-oleh ini juga digunakan sebagai official souvenir PT Petrokimia Gresik.

g. Optimalisasi Trepan Creative Space. Trepan Creative Space menjadi salah satu ruang yang dapat digunakan oleh kelompok dalam mengembangkan produk serta kapasitas setiap anggotanya melalui sharing knowledge 
kepada anggota kelompok lain dan masyarakat luas.

\section{HASIL DAN LUARAN}

\section{Pelibatan dan Pengembangan Masyarakat, apa dan bagaimana?}

ISO 26000 menjelaskan pelibatan dan pengembangan masyarakat umumnya dipahami sebagai upaya untuk meningkatkan kualitas hidup masyarakat. Di mana seperti yang diketahui bahwa pengembangan masyarakat merupakan suatu proses jangka panjang serta terdapat potensi munculnya kepentingan yang berbeda dan saling bertentangan. Karakteristik sejarah dan budaya membuat setiap komunitas unik dan mempengaruhi kemungkinan masa depannya. Oleh karena itu, pengembangan masyarakat merupakan hasil sosial, politik, ekonomi, dan budaya yang bergantung ada karakteristik kekuatan sosial yang terlibat di dalamnya.

Pemberian peranan yang lebih besar kepada masyarakat untuk terlibat dalam program pembangunan dapat memberikan dampak positif bagi proses pembangunan berkelanjutan (Soetomo, 2012, hal. 354). Hal ini disebabkan masyarakat tidak hanya bergantung pada perusahaan sebagai pemberi program. Menurut Emil Salim dalam (Soetomo, 2012:355) pembangunan berkelanjutan tidak terbatas pada pengeolaan sumber daya alam secara berkelanjutan, tetapi juga keberlanjutan sosial dan ketahanan sosial. Hal ini berarti bahwa potensi manusia dan potensi sosial dalam masyarakat lebih dapat dikembangkan. Dalam kondisi tersebut, masyarakat memiliki wadah untuk menyalurkan aspirasi maupun potensinya pun jika terdapat ketidakpuasan atas kondisi yang ada (Soetomo, 2012, hal. 355).

Pelibatan dan pengembangan masyarakat dalam program CSR menjadi hal yang sangat berpengaruh dalam keberhasilan program. Sebelum menginisiasi suatu program, perusahaan terlebih dahulu meneliti potensi dampak dari perusahaan itu sendiri terhadap masyarakat sehingga dapat meminimalkan dampak negatif serta memaksimalkan dampak positif. Identifikasi yang dilakukan perusahaan dapat melalui pelibatan masyarakat untuk kemudian dapat menentukan kegiatan yang tepat dalam pengembangan masyarakat. Karena pada dasarnya kegiatan CSR yang dilakukan perusahaan disesuaikan dengan hal-hal khusus yang ada dalam masyarakat seperti pengetahuan unik, sumber daya dan kapasitas yang ada. Dengan mengintegrasikan konsep keterlibatan masyarakat ke dalam keputusan yang diambil dan kegiatan yang dilakukan, perusahaan dapat memaksimalkan pembangunan berkelanjutan di masyarakat (International Organization for Standarization, 2010, hal. 63).

\section{Forum Monitoring Stakeholders}

Kegiatan pengembangan kapasitas UMKM di era new normal tidak terbatas pada pengembangan pengetahuan mengenai pengelolaan usaha. Akan tetapi juga mengasah kepekaan para pelaku usaha dalam mengidentifikasi masalah dan mencari solusi atas masalah serta potensi masalah yang mungkin dihadapi. Pelibatan masyarakat mulai dalam identifikasi masalah, penyusunan rencana kegiatan, dan pelaksanaan kegiatan pengembangan masyarakat menjadi upaya peningkatan kesadaran masyarakat akan kegiatan ekonomi yang berkelanjutan.

Penyusunan rencana kerja tahunan dilakukan pada Januari - Maret 2021 dengan melibatkan para pemangku kepentingan dari sektor private, state, dan civil society. Pada 25 Maret 2020, dilaksanakan FGD fiksasi rencana kerja tahunan Program Kampung Pisang Trepan di Balai Desa Trepan. Kegiatan ini dihadiri oleh seluruh pemangku kepentingan dari 3 sektor yaitu KUB Pemuda Kreatif Trepan, Gapoktan, PT Haza Foods Indonesia, dan Pemerintah Desa Trepan. Hasil dari FGD ini adalah rangkaian strategi/metode pengembangan masyarakat di era new normal untuk mewujudkan Desa 
Wisata Pisang Trepan. Adapun metode tersebut di bab sebelumnya.

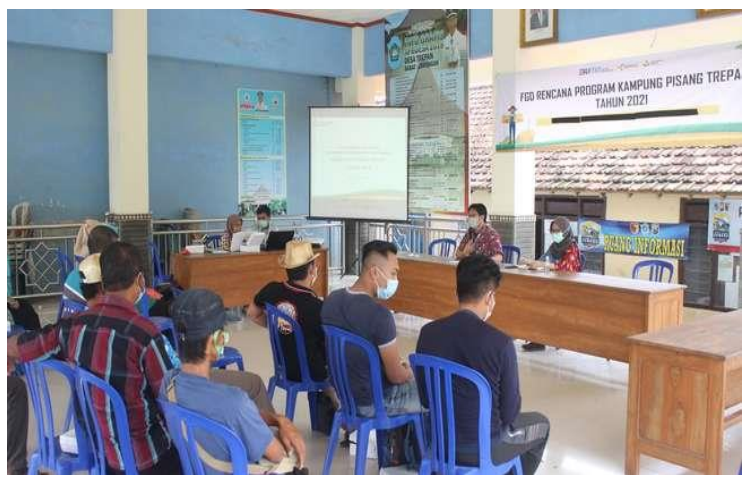

Gambar 2. FGD Renstra Renja Program Kampung Pisang Trepan

Forum monitoring menjadi salah satu cara yang paling tepat untuk mejalin engagement perusahaan, penerima manfaat dan para pemangku kepentingan. Melalui forum ini, penulis dapat mengidentifikasi masalah dan memetakan aktor-aktor yang berpengaruh dalam setiap keputusan yang diambil dalam forum. Pandangan baru mengenai strategi pemecahan masalah juga sering ditemukan dalam diskusi forum monitoring ini.

\section{Akselerasi Produk UMKM}

Kegiatan yang berkaitan dengan pengembangan produk UMKM Kampung Pisang Trepan sempat terhambat pada masa pandemi Covid-19. Melihat permasalahan tersebut, pada tahun 2021 dilakukan penyesuaian kegiatan dengan tetap menerapkan prinsip CID. Dari hasil wawancara dan FGD ditemukan bahwa manajemen sumber daya manusia dan manajemen keuangan menjadi hambatan pengembangan usaha. Manajemen usaha belum bisa optimal karena masing-masing UMKM hanya beranggotakan 1-3 orang. Oleh karena itu dibentuk Kelompok Usaha Bersama (KUB) Pemuda Kreatif Trepan yang menggabungkan UMKM Ibana Craft, Sahitya, Kennes Cake, dan Manoora dalam satu organisasi yang terdaftar dalam Akta Notaris . Berikut data perubahan kelompok UMKM menjadi KUB Pemuda Kreatif Trepan:
Tabel 1. Data perubahan anggota kelompok UMKM

\begin{tabular}{|c|c|c|}
\hline \multirow{2}{*}{ UMKM } & \multicolumn{2}{|c|}{ Jumlah Anggota } \\
\cline { 2 - 3 } & Sebelum & $\begin{array}{c}\text { Sesudah (KUB } \\
\text { Pemuda Kreatif } \\
\text { Trepan) }\end{array}$ \\
\hline Ibana Craft & 1 & 5 \\
\hline Sahitya & 2 & 2 \\
\hline $\begin{array}{c}\text { Kennes } \\
\text { Cake }\end{array}$ & 3 & 3 \\
\hline Manoora & - & 1 \\
\hline
\end{tabular}

Sumber: Data CSR PT Petrokimia Gresik 2021

Masalah manajemen usaha termasuk belum adanya pencatatan keuangan usaha. Upaya pemecahan masalah tersebut dilakukan melalui pelatihan manajemen keuangan. Pelatihan dilaksanakan pada 29 Maret 2021 dengan materi pembukuan, refreshment penghitungan HPP, pemasaran, dan transaksi digital. Semula, para pelaku UMKM KUB Pemuda Kreatif Trepan tidak memiliki catatan keuangan usaha sama sekali. Kemudian diberikan pelatihan dengan materi pengelola keuangan dan penggunaan sistem kasir digital menggunakan aplikasi iKas. Dengan menggunakan aplikasi ini, KUB Pemuda Kreatif Trepan dimudahkan dalam melakukan pencatatan penjualan produk. Disamping itu, fasilitator dari PT Petrokimia Gresik dapat memantau flow transaksi KUB Pemuda Kreatif Trepan melalui dashboard online. 


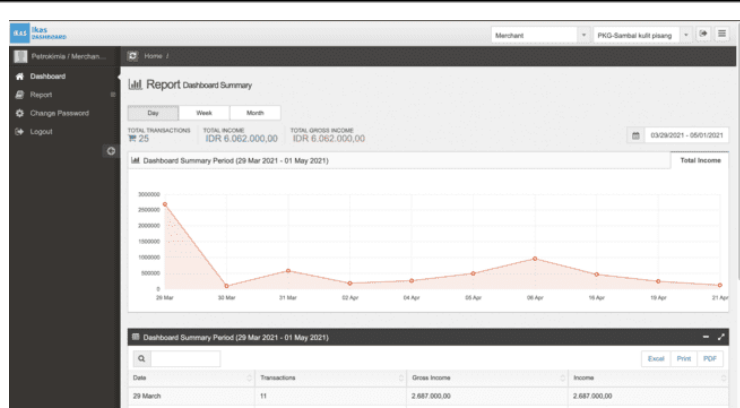

Gambar 3. Dasboard Pemantauan Transaksi KUB Pemuda Kreatif Trepan

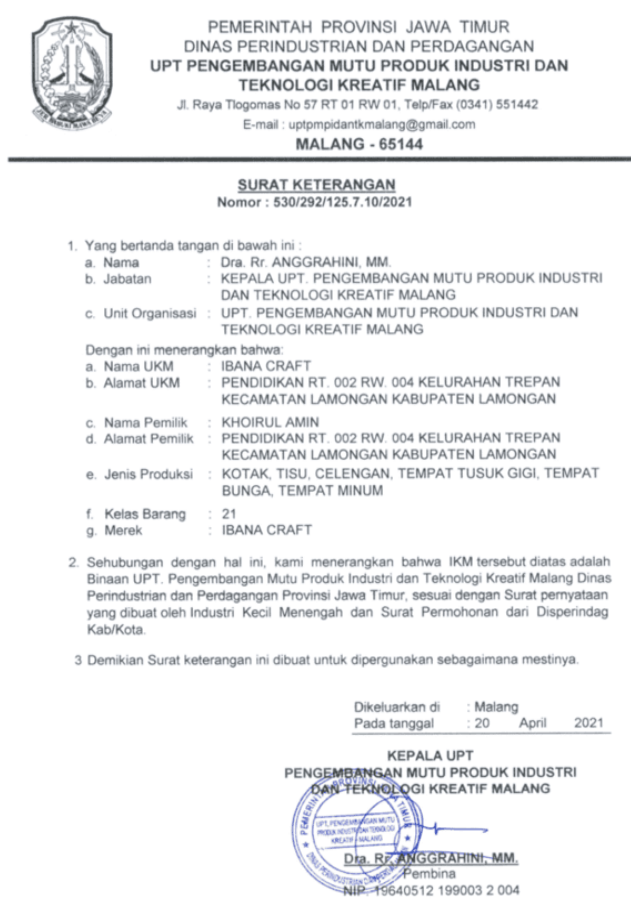

Gambar 6. Surat Keterangan Hak Merk

Setiap UMKM difasilitasi 1 akun user iKas dan 1 buah printer kasir. Transaksi penjualan yang di rekap dalam aplikasi ini dapat di export dalam format pdf dan excel.

\begin{tabular}{|l|r|l|l|}
\hline undefined & & & \multicolumn{1}{l}{} \\
\hline Date & Transactions & Gross Income & Income \\
\hline 29 March & 11 & $2.687 .000,00$ & $2.687 .000,00$ \\
\hline 30 March & 2 & $90.000,00$ & $90.000,00$ \\
\hline 31 March & 3 & $575.000,00$ & $575.000,00$ \\
\hline 02 April & 1 & $180.000,00$ & $180.000,00$ \\
\hline 04 April & $1260.000,00$ & $260.000,00$ \\
\hline 05 April & $1490.000,00$ & $490.000,00$ \\
\hline 06 April & 2 & $960.000,00$ & $960.000,00$ \\
\hline 16 April & 2 & $460.000,00$ & $460.000,00$ \\
\hline 19 April & $1240.000,00$ & $240.000,00$ \\
\hline 21 April & 1 & $120.000,00$ & $120.000,00$ \\
\hline
\end{tabular}

Gambar 4. Data Transaksi Penjualan Produk

Pengembangan kapasitas internal kelompok melalui pelatihan dan digitalisasi transaksi ini paralel dengan pengajuan izin halal dan pendaftaran barcode produk olahan makanan. Disamping itu, dilakukan pendaftaran hak merk bagi kelompok kerajinan limbah pelepah pisang. Pendaftaran izin tersebut dilakukan dengan prosedur mandiri. Pada April 2021, barcode produk olahan makanan dan hak merk kerajinan telah terdaftar. Sementara, pengurusan izin halal masih dalam proses.

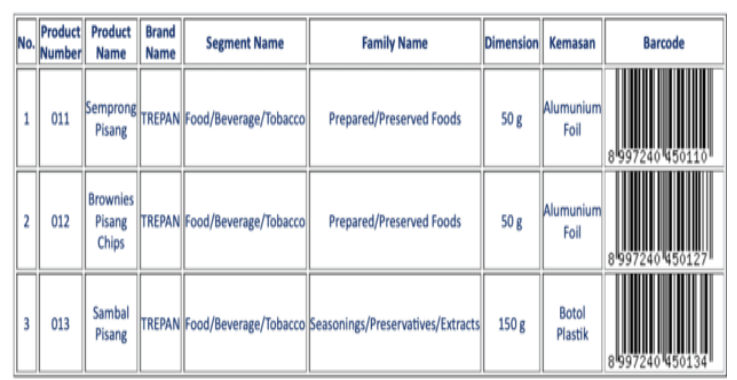

Gambar 5. Barcode Produk Olahan Makanan

Akselerasi produk UMKM ini merupakan upaya untuk membangkitkan kembali gairah pengembangan diri para pelaku usaha sekaligus menguatkan manajemen usaha dalam menghadapi masa new normal. Tidak cukup sampai disitu, PT Petrokimia Gresik juga menerapkan konsep Creating Shared Value (CSV) melalui pembuatan paket oleh-oleh dari produkproduk KUB Pemuda Kreatif Trepan. Paket 
oleh-oleh tersebut dapat digunakan sebagai official souvenir perusahaan serta bagi pengunjung Desa Wisata Pisang Trepan. Paket oleh-oleh terdiri dari tas pelepah pisang yang digunakan sebagai packaging, 4 varian rasa semprong pisang, 3 varian rasa brownies cips, dan 3 varian rasa sambal pisang dengan harga Rp225.000,-. Melalui paket oleh-oleh ini, KUB Pemuda Kreatif Trepan mendapatkan keuntungan berupa pasar yang pasti. Sementara itu, perusahaan mendapatkan official souvenir berkualitas dengan harga yang murah.

\section{Trepan Creative Space, apa dan untuk siapa?}

Trepan Creative Space merupakan bangunan pusat kegiatan creative preneur bagi KUB Pemuda Kreatif Trepan dan masyarakat Desa Trepan. Bangunan ini terdiri dari area outdoor. Area indoor digunakan sebagai ruang pertemuan dan showroom produk KUB Pemuda Kreatif Trepan. Sedangkan area outdoor dapat digunakan oleh Ibana Craft dalam produksi kerajinan. Adanya Trepan Creative Space ini meningkatkan intensitas kegiatan pemuda dan masyarakat, khususnya KUB Pemuda Kreatif Trepan dalam kegiatan sharing knowledge terkait pengembangan dan pemasaran produk UMKM. Hal ini menjadi stimulan yang baik bagi kelompok untuk menghadapi era new normal.

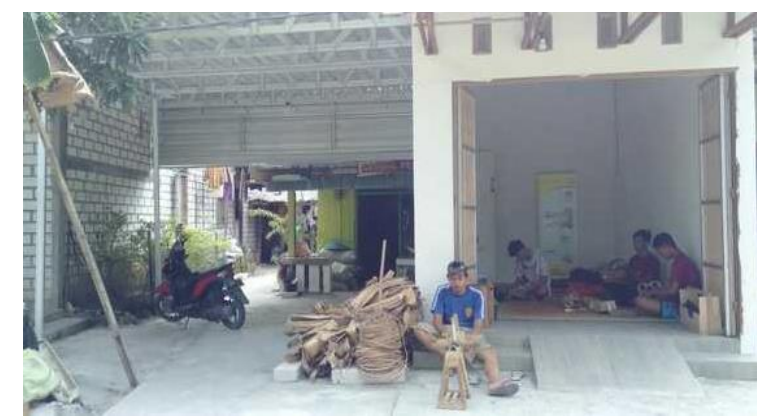

Gambar 7. Aktivitas Pemuda di Trepan Creative Space

Program pengembangan masyarakat ini telah menjangkau 4 kelompok UMKM di Desa Trepan. Dengan strategi pengembangan masyarakat di era new normal, diharapkan KUB Pemuda Kreatif Trepan mampu survive dan meningkatkan pendapatan mereka. Pelaksanaan CID Program Kampung Pisang Trepan juga diselaraskan dengan Sustainable Development Goals (SDGs) melalui empat inisiatif pemberdayaan yaitu peningkatan kualitas pendidikan, peningkatan kualitas lingkungan hidup, peningkatan ekonomi, dan pemberdayaan masyarakat. Berikut adalah implementasi CID Program Kampung Pisang Trepan di era new normal dalam mencapai SDGs:

Tabel 2. Data Capaian SDGs Program Kampung Pisang Trepan

\begin{tabular}{|l|l|}
\hline \multicolumn{1}{|c|}{$\begin{array}{c}\text { Indikator } \\
\text { SDGs }\end{array}$} & \multicolumn{1}{|c|}{ Capaian } \\
\hline $\begin{array}{l}\text { 4. Pendidikan } \\
\text { berkualitas }\end{array}$ & $\begin{array}{l}\text { Program ini berkontribusi } \\
\text { meningkatkan kompetensi } \\
\text { tambahan anggota } \\
\text { sejumlah 72\% (Data } \\
\text { perbandingan penerima } \\
\text { manfaat yang mengikuti } \\
\text { pelatihan dengan jumlah } \\
\text { total penerima manfaat) }\end{array}$ \\
\hline $\begin{array}{l}\text { 8. Pekerjaan } \\
\text { Layak dan } \\
\text { Pertumbuhan } \\
\text { Ekonomi }\end{array}$ & $\begin{array}{l}\text { Program ini berkontribusi } \\
\text { menurunkan } \\
\text { pengangguran terbuka } \\
\text { sebesar 0.0006\% dari } \\
\text { jumlah pengangguran } \\
\text { terbuka di Kabupaten } \\
\text { Lamongan }\end{array}$ \\
\hline $\begin{array}{l}\text { 12. Konsumsi } \\
\text { dan Produksi } \\
\text { yang } \\
\text { Bertanggung } \\
\text { Jawab }\end{array}$ & $\begin{array}{l}\text { Program ini berkontribusi } \\
\text { dalam mengurangi limbah } \\
\text { melalui pengurangan dan } \\
\text { daur ulang limbah } \\
\text { pelepah pisang menjadi } \\
\text { kerajinan sebesar 10 } \\
\text { kwintal/bulan }\end{array}$ \\
\hline Sumber: Data
\end{tabular}
2021

\section{KESIMPULAN DAN SARAN}

KUB Pemuda Kreatif Trepan masih perlu pengembangan dalam manajemen usaha. Para pelaku UMKM secara keseluruhan masih belum memiliki mental wirausaha yang kuat. Terutama ibu-ibu 
Sahitya, Kennes Cake dan Manoora yang cenderung menjadikan usahanya sebagai pengisi waktu luang sehingga kurang berkembang, tidak inovatif, dan jaringan pemasaran yang sempit.

CID melalui berbagai kegiatan dalam Program Kampung Pisang Trepan ini membuka wawasan dan pemahaman bagi para pelaku usaha terkait berbagai peluang pengembangan usaha dan pemasaran produk di era new normal. Pendampingan secara intensif oleh PT Petrokimia Gresik juga dilakukan bagi para pelaku UMKM ini terkait pengembangan kapasitas individu, advokasi masalah, dan pengembangan usaha. Pendampingan ini bekerjasama dengan mentor yang ahli di bidang UMKM yaitu Muhammad Zain dari PT Haza Foods Indonesia, Anindityo dari PT Global Sukses Solusi (iKas), dan Faris Budianto dari PT Ikanovasi Karya Lokal (Sipetek). Pendampingan ini merupakan kegiatan yang interaktif antara penerima manfaat, fasilitator perusahaan dan mentor.

\section{UCAPAN TERIMAKASIH}

Kepada KUB Pemuda Kreatif Trepan, GAPOKTAN Desa Trepan, Manajemen PT Petrokimia Gresik, Pemerintah Desa Trepan, dan buku-buku pengembangan masyarakat yang kami baca.

\section{DAFTAR PUSTAKA}

Amri, A. (2020). Dampak Covid-19 terhadap UMKM di Indonesia. Jurnal Brand, 2(1), 123-130.

International Organization for Standarization. (2010). ISO 26000:

Guidance Standar on Social Responsibility. 10-13. Switzerland: ISO copyright office.

Selener, D. (1997). Participatory Action Research and Social Change. New York: The Cornell Participatory Action Research Network.

Soetjipto, N. (2020). Ketahanan UMKM Jawa Timur Melintasi Pandemi Covid-19. Yogyakarta: K-Media.
Soetomo.

(2012).

Pembangunan

Masyarakat: Merangkai Sebuah

Kerangka. Yogyakarta: Pustaka Pelajar. 